\title{
Contextual Teaching And Learning (Ctl) Learning Model Using The Module For Futsal Courses, Department Of Sports Training Education, Faculty Of Sports Science, Surabaya State University
}

\author{
Arif Bulqini, Lecturer at the Department of Sports Coaching Education, Faculty of Sports Science, \\ Universitas Negeri Surabaya, Indonesia, arifbulqini@unesa.ac.id \\ Agus Wiyono, Lecturer at the Department of Building Engineering Education, Faculty of Engineering, \\ Universitas Negeri Surabaya, Indonesia , aguswiyono@unesa.ac.id
}

\begin{abstract}
The study aims to determine (1) the feasibility of implementing the module using the Contextual Teaching and Learning (CTL) learning model, (2) student learning outcomes in implementing the module, (3) students' responses to the module implementation in the Futsal course. The research adopts the True Experimental Design with Posttest Only Control Design research type. The population is students of Sports Coaching Education, with the samples are the 2018 and 2019 classes of the Sports Coaching Education Department, Faculty of Sports Science, Surabaya State University. The research instrument is a module validation sheet validated by an expert lecturer in Sports Coaching Education, Surabaya State University. Validation by expert lecturers resulted in a percentage value of $77.5 \%$ and is categorized as feasible according to the assessment size criteria table and the score weight. The literature review stage, which compares five relevant studies using the CTL learning model, concludes that using the teaching and learning activities model is very efficient and worthy to improve student learning outcomes.
\end{abstract}

Keywords: Contextual Teaching and Learning, CTL, Modul, Learning Outcomes

Received: 05.12.2020 Accepted: 13.01.2021 $\quad$ Published: 07.02.2021

\section{INTRODUCTION}

Education has a vital role in developing knowledge and skills. It can be said that education is an effort that is considered essential in human life. One of the factors that support success in education is the availability of learning media students use in teaching and learning activities in class. According to Hamalik in Arsyad (2011: 15), instructional media in teaching and learning activities can generate new desires and interests, create motivation and stimulation of teaching and learning activities, and bring psychological influences.

The initial survey conducted in the Sports Coaching Education department, with lecturers in the Futsal subject, shows that high school graduate students do not know fully about Futsal and have never learned how to operate AutoCAD software high school education level in the Futsal class. The absence of a visual view requires drawing illustrations and steps in the operation of the AutoCAD software.

According to Arsyad (2011: 21), the media serves to provide information to students to be actively involved in realizing the learning process, either in the form of mental or real activities. By using learning media, students are invited to be more active in the learning process to affect their atmosphere and conditions. In describing his table, Arsyad (2011: 79) reveals that the selection of media according to the content of the lesson and media use involving printed media and illustrated images has high benefits and effectiveness. Therefore we need learning media that can be useful for lecturers and students, such as modules using the Contextual Teaching and Learning (CTL) learning model.

Problem formulations are found from the background and problems described above: (1) What is the feasibility of implementing the module using the CTL learning model in the Futsal course? (2) How are the student learning outcomes in implementing modules using the CTL learning model in the Futsal course?

The study aims to determine: (1) the appropriateness of implementing the module using the CTL learning model in the Futsal course, (2) student learning outcomes in implementing the module using the CTL learning model in building drawing courses, (3) Student responses to the application. The module uses the CTL learning model in the Futsal course.

The study has two limitations. This study's first limitation is the 2D Futsal course using AutoCAD software on drawing material or projecting a longitudinal and cross-sectional image of a 2-story house 
building according to the cut lines found in the floor plan. The second limitation is that the sample used is students in 2018 and 2019 majoring in Sports Coaching Education, Faculty of Sports Science, Surabaya State University, as the control class.

There are several benefits of the research. The first benefit is to provide students with an effective way to be more active in the classroom through the Contextual Teaching and Learning (CTL) learning model. It is hoped that learning can be more independent and effective in the Futsal course using module learning media. Lecturers can use the research as a reference for learning media and learning models. For researchers, research can provide innovations in module learning media applications suitable for lecturers' teaching materials to improve student skills in using AutoCAD software. Finally, research can become a reference material for future researchers to develop pre-existing media modules for universities.

\section{LITERATURE REVIEW}

Arsyad (2011: 15) says that there are two essential elements in a teaching and learning process: the teaching model and learning media. The two aspects are closely related so that the teaching model's selection dramatically affects the appropriate type of learning media. However, other media selection aspects include learning objectives, types of assignments, and student responses.

The module is a book written with the aim that students can learn independently without or with teacher guidance. Modules are interpreted as teaching materials presented systematically to learn with or without a facilitator (Prastowo 2015: 104). According to Surahman (2010: 2), the module is the smallest unit of a learning program that students can learn individually (self-instructional).

The learning model is a pattern used as a guide in planning classroom learning (Suprijono, 2009: 46). Teachers can help students get information, ideas, skills, ways of thinking, and express their ideas using the CTL learning model.

Hamdayana (2014: 51) argues that the CTL approach is a learning concept that helps teachers link the material being taught with students' real-world situations. It encourages students to make connections between their knowledge and their lives as family members and society. Through this understanding, learning outcomes are expected to be more meaningful for students.

CTL is a learning concept where the teacher presents the real world into the classroom and encourages students to connect their knowledge and application in everyday life. Students acquire knowledge and skills in a limited context little by involving the seven main components of effective learning: constructivism, questioning, inquiry, learning community, modeling, reflection, and authentic assessment."

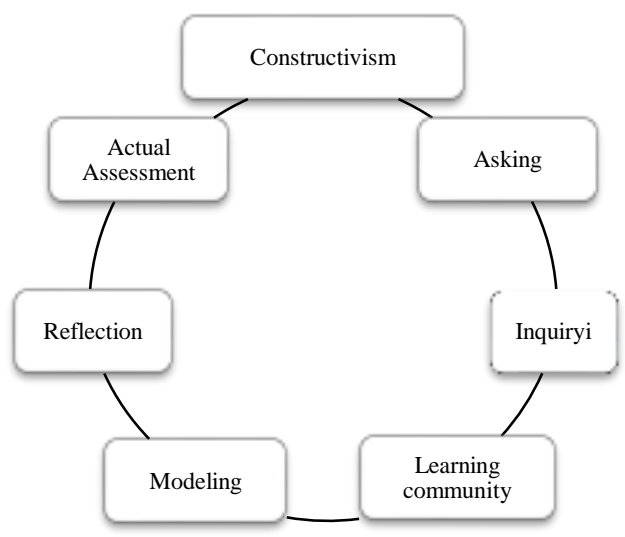

Figure 1. Components of a Contextual Learning Approach

Supratiknya (2012: 5) suggests that learning outcomes that are the object of class assessment are in the form of new abilities obtained by students after they participate in individual subjects' teaching and learning process. In the national education system, the formulation of educational goals refers to the classification of Bloom's learning outcomes, which broadly consists of cognitive, affective, and psychomotor aspects.

According to the guidebook for the Faculty of Sports Science, the Futsal course is a course that introduces various functions and ways of using drawing tools; lines, letters, numbers, and their operations. It describes visual projections, orthogonal, and perspectives of civil engineering buildings. The course teaches how to draw simple residential building structures sliced from plans, foundation 
plans, roof plans, longitudinal sections, cross-sections, side views, sanitation plans, mechanical and electrical engineering, and structural details in simple houses AutoCAD software.

Tamrin (2008: 6) suggests that a cutout image is an image of a building projected on a vertical plane. Its position is taken in certain places, especially in the negative (down) floor estimate. The cutout image shows all the materials, both exterior, and interior, that will be used. It is equipped with instructions that are the key to the building system, such as mechanical parts, plumbing, etc. The detailed functions of the cutout image are displaying (1) the contents and each room according to its function, (2) precise dimensions of space, (3) detailed elevation of each room, and (4) the materials used.

According to Suparno (2008: 317), AutoDesk is an American company that creates software to help design, namely Computer-Aided Design (CAD). The software is AutoCAD, which is currently being used in various fields of Sports Science, including architecture, machinery, automotive, surveying, and mapping.

AutoCAD is one of the most widely used CAD software by businesses or industries, and individuals. The software offers various drawing facilities, both 2-dimensional and 3-dimensional, accurately and has many facilities to speed up the drawing process. AutoCAD has become the standard software for IBM (International Business Machines) PC (Personal Computer) so that the supporting hardware always provides drivers for AutoCAD.

Dia Cahya Puspa Sari (2017: 81) suggests that implementing modules with a contextual approach to learning mechanics in Sports Science on the learning outcomes of 27 students shows that $74.1 \%$ of students complete learning according to the Minimum Completeness Criteria, and $25.9 \%$ of students have not finished. Meanwhile, the average class score was 75.7. It shows that the module with a contextual approach to the learning mechanics of Sports Science can help TKBB class X students understand the material to achieve the completeness set at State Vocational High School 2 Bojonegoro.

The research results from the journal Irhamuddin (2017: 54) suggest that the implementation of learning using modules obtained an excellent average score of $85.11 \%$. Based on the categories, the performance of learning using modules is carried out very well.

The results of research from the journal Hasabi Vidi Koes Prabowo (2018: 74) suggest that the implementation of the direct learning model using modules at the first meeting got a percentage of $87.00 \%$ (teachers) and $81.00 \%$ (students) and at the second meeting got $88.00 \%$ (Teachers) and $84.00 \%$ (Students). Implementing the direct learning model for class XI students of SMK Negeri 2 Bangkalan using modules is very well executed. Students can learn independently with the module, so it can be concluded that the implementation of the Sports Science module building drawings in class XI TGB State Vocational High School 2 Bangkalan is in the excellent category.

\section{METHODOLOGY}

The type of research used is True Experimental Design research. Sugiyono (2015: 112) says that the design has a control group. Using the design, the researcher can control all external variables that affect the course of the experiment. The method is research used to determine the effect of specific treatments on the control group.

The study uses a Posttest Only Control Design, namely from 2 groups (classes), only 1 group is given treatment while the other group is not. The research is carried out according to the flow listed below: 


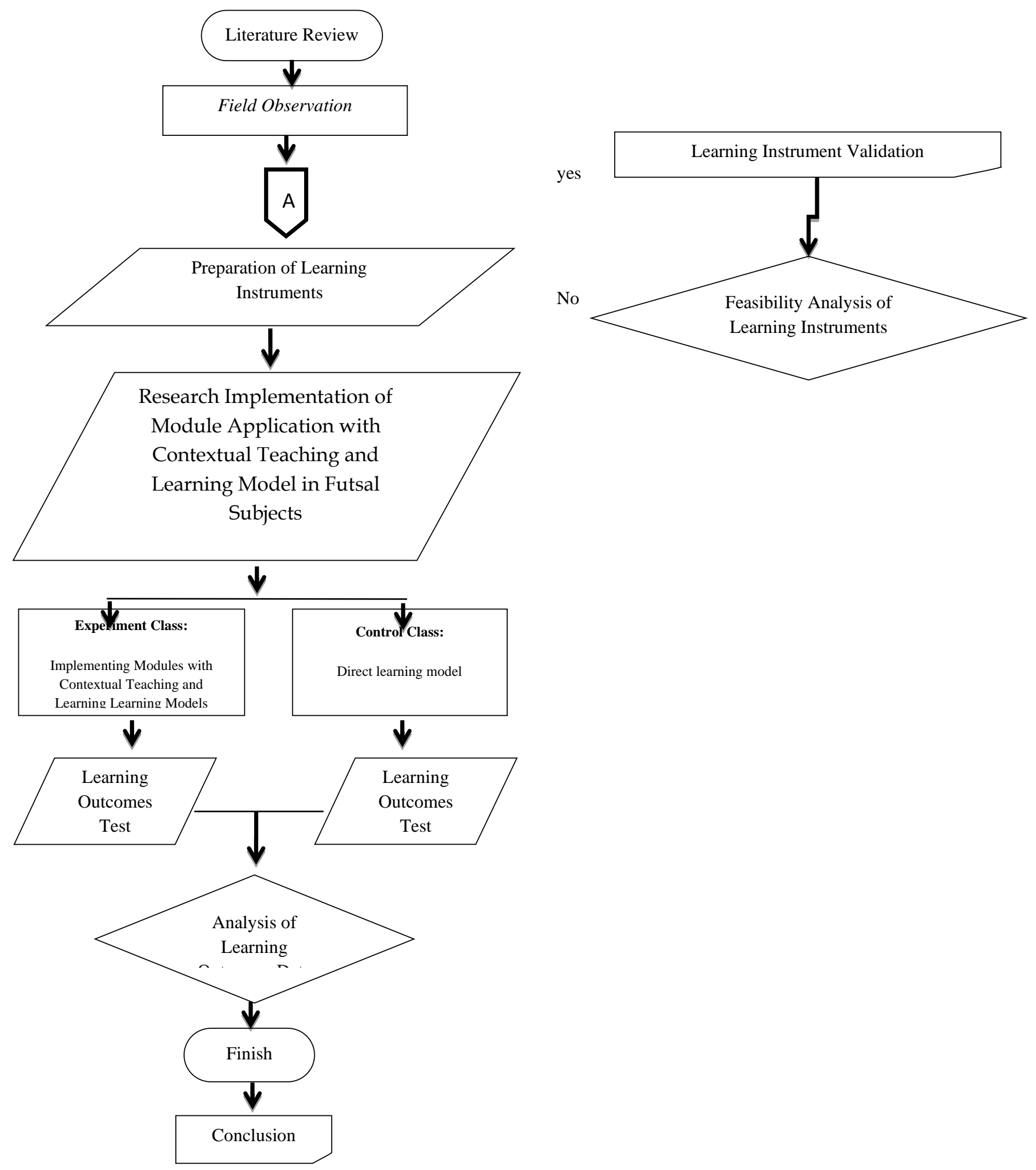

Figure 2. Research Design Flowchart

Researchers used analytical research to test the products' effectiveness required by the research design to produce products from the study. The following is a research design Posttest Only Control Design. 
The implementation of the research was carried out in the Department of Sports Coaching \begin{tabular}{|l|l|l|l|l|l|}
\hline No & Meeting & Class & CTL & Modul & Material \\
\hline
\end{tabular} Education, the State University of Surabaya in the Sports Coaching Education study program, which was held in semester 2 for the Futsal course in the 2019/2020 school year. The feasibility analysis of learning media is carried out using a questionnaire sheet, which will be filled in by the validator, namely expert lecturers or practitioners. The questionnaire contains statements that are given an assessment score in the form of numbers $1,2,3,4$, and 5 [The scoring in the questionnaire is based on the following conditions: Score $5=$ Very Good, Score 4 = Good, Score 3 = Medium, Score $2=$ Bad, Score $1=$ Very bad]. Assessment and validation by expert lecturers/practitioners using the following media and learning tools.

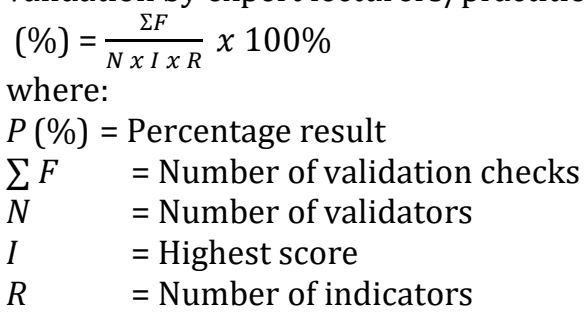

\section{DISCUSSION}

The module learning media's validation is carried out using a questionnaire sheet filled out by two expert lecturers from the Department of Sports Coaching Education, State University of Surabaya. The indicators that are assessed by the validator lecturer include (1) physical modules, (2) application, knowledge and drawing skills, (3) language, (4) writing system.

\section{Validation Results of Module Learning Media}

Module validation data is generated by conducting assessments carried out by two expert lecturers in drawing courses using the AutoCad application.

The module validation results by two expert lecturers are processed using the Riduwan formula (2015: 14), which states that the learning media is feasible if the validator's average value is $\geq 61 \%$.

Through Riduwan's formula, the average value of the physical aspect of the module has a percentage of $80 \%$, the average value of the application aspect, knowledge and drawing skills has a percentage of $83.33 \%$, the average value of the linguistic aspect has a percentage of $66.67 \%$, the average value of the writing aspect has a percentage of $90 \%$. formula:

The percentage of eligibility for module learning media can be calculated using the following

$$
\begin{aligned}
& \mathrm{P}(\%)=\frac{\sum \mathrm{F}}{\mathrm{N} \times \mathrm{I} \times \mathrm{R}} \times 100 \% \\
& \quad \begin{array}{l}
\text { Source: Riduwan, 2015:14) } \\
(8+9+8+8+7+6+7+9)
\end{array} \\
& \mathrm{P}(\%)=\frac{62 \times 5 \times 8)}{(2 \times 100} \\
& \mathrm{P}(\%)=\frac{62}{80} \times 100 \% \\
& \mathrm{P}(\%)=77,5 \%
\end{aligned}
$$

The calculation of the feasibility of the module learning media from Riduwan's formula is $77.5 \%$. According to table 2 regarding the criteria for score interpretation, the percentage of $77.5 \%$ of the formula calculation results is in the interval of $61 \%-80 \%$, so that the learning media modules, which are assessed by expert lecturers, can be categorized as modules that are feasible to use. 


\begin{tabular}{|c|c|c|c|c|c|}
\hline \multirow{2}{*}{1.} & \multirow{2}{*}{ Meeting 1} & $\begin{array}{l}\text { SCE } \\
2019\end{array}$ & $\sqrt{ }$ & $\sqrt{ }$ & $\begin{array}{l}\text { Carry out the kicking ball } \\
\text { game technique (using the } \\
\text { inside leg, back of the } \\
\text { foot \& outside foot) }\end{array}$ \\
\hline & & $\begin{array}{l}\text { SCE } \\
2018\end{array}$ & - & - & $\begin{array}{c}\text { Carry out the kickball } \\
\text { game technique (using the } \\
\text { inner leg, instep \& outer } \\
\text { leg) }\end{array}$ \\
\hline \multirow{2}{*}{2.} & \multirow{2}{*}{ Meeting 2} & $\begin{array}{l}\text { SCE } \\
2019\end{array}$ & $\sqrt{ }$ & $\sqrt{ }$ & $\begin{array}{l}\text { Carry out basic dribbling } \\
\text { technique skills }\end{array}$ \\
\hline & & $\begin{array}{l}\text { SCE } \\
2018\end{array}$ & - & - & $\begin{array}{l}\text { Carry out basic dribbling } \\
\text { technique skills }\end{array}$ \\
\hline \multirow{2}{*}{3.} & \multirow{2}{*}{ Meeting 3} & $\begin{array}{l}\text { SCE } \\
2019\end{array}$ & \multicolumn{2}{|c|}{ Posttest } & $\begin{array}{c}\text { Carry out basic ball } \\
\text { control technique skills }\end{array}$ \\
\hline & & $\begin{array}{l}\text { SCE } \\
2018\end{array}$ & \multicolumn{2}{|c|}{ Posttest } & $\begin{array}{c}\text { Carry out basic ball } \\
\text { control technique skills }\end{array}$ \\
\hline No & Meeting & Class & CTL & Modul & Material \\
\hline \multirow{2}{*}{1.} & \multirow{2}{*}{ Meeting 1} & $\begin{array}{l}\text { SCE } \\
2019\end{array}$ & $\sqrt{ }$ & $\sqrt{ }$ & $\begin{array}{l}\text { Carry out the kicking ball } \\
\text { game technique (using the } \\
\text { inside leg, back of the } \\
\text { foot \& outside foot) }\end{array}$ \\
\hline & & $\begin{array}{r}\text { SCE } \\
2018\end{array}$ & - & - & $\begin{array}{c}\text { Carry out the kickball } \\
\text { game technique (using the } \\
\text { inner leg, instep \& outer } \\
\text { leg) }\end{array}$ \\
\hline \multirow{2}{*}{2} & \multirow{2}{*}{ Meeting 2} & $\begin{array}{l}\text { SCE } \\
2019\end{array}$ & $\sqrt{ }$ & $\sqrt{ }$ & $\begin{array}{l}\text { Carry out basic dribbling } \\
\text { technique skills }\end{array}$ \\
\hline & & $\begin{array}{l}\text { SCE } \\
2018\end{array}$ & - & - & $\begin{array}{l}\text { Carry out basic dribbling } \\
\text { technique skills }\end{array}$ \\
\hline \multirow{2}{*}{3.} & \multirow{2}{*}{ Meeting 3} & $\begin{array}{l}\text { SCE } \\
2019 \\
\end{array}$ & \multicolumn{2}{|c|}{ Posttest } & $\begin{array}{c}\text { Carry out basic ball } \\
\text { control technique skills }\end{array}$ \\
\hline & & $\begin{array}{l}\text { SCE } \\
2018\end{array}$ & \multicolumn{2}{|c|}{ Posttest } & $\begin{array}{l}\text { Carry out basic ball } \\
\text { control technique skills }\end{array}$ \\
\hline
\end{tabular}

Table 1.

Table 2.

\begin{tabular}{|c|c|c|}
\hline Percentage & core Weight & Interpretation \\
\hline $\mathbf{0} \% \mathbf{- 2 0} \%$ & 1 & Very Unworthy \\
\hline $\mathbf{2 1} \% \mathbf{- 4 0} \%$ & 2 & Not feasible \\
\hline $\mathbf{4 1} \% \mathbf{- 6 0} \%$ & 3 & Average \\
\hline $\mathbf{6 1} \% \mathbf{- ~ 8 0 \%}$ & 4 & Feasible \\
\hline $\mathbf{8 1} \% \mathbf{- 1 0 0} \%$ & 5 & Very Feasible \\
\hline
\end{tabular}

Table 3. Recapitulation of Feasibility Validation Calculation for Learning Media Module

\begin{tabular}{|c|c|c|c|c|c|c|}
\hline \multirow[t]{2}{*}{ Indicator } & \multicolumn{3}{|c|}{$\begin{array}{l}\text { Validator's } \\
\text { Answer }\end{array}$} & \multirow[t]{2}{*}{ Total } & \multirow[t]{2}{*}{$\begin{array}{l}\text { Result } \\
(\%)\end{array}$} & \multirow[t]{2}{*}{ Criteria } \\
\hline & 1 & 2 & 3 & & & \\
\hline $\begin{array}{l}\text { Physical Module } \\
\text { The cover module is attractive and contains } \\
\text { elements of the title and logo of the university. }\end{array}$ & 3 & 5 & & 8 & 80 & Feasible \\
\hline $\begin{array}{l}\text { Application, knowledge, and drawing skills } \\
\text { The information conveyed is legible. } \\
\text { The order of images and text is related. } \\
\text { The image caption is clear enough. }\end{array}$ & $\begin{array}{l}4 \\
4 \\
4\end{array}$ & $\begin{array}{l}5 \\
4 \\
4\end{array}$ & & $\begin{array}{l}9 \\
8 \\
8\end{array}$ & $\begin{array}{l}90 \\
80 \\
80\end{array}$ & $\begin{array}{l}\text { Very } \\
\text { Feasible } \\
\text { Feasible } \\
\text { Feasible }\end{array}$ \\
\hline $\begin{array}{l}\text { Language } \\
\text { Language is easy to understand } \\
\text { Language according to enhanced spelling } \\
\text { Language does not mean double }\end{array}$ & $\begin{array}{l}4 \\
4 \\
4\end{array}$ & $\begin{array}{l}4 \\
4 \\
4\end{array}$ & & $\begin{array}{l}8 \\
8 \\
8\end{array}$ & $\begin{array}{l}80 \\
80 \\
80\end{array}$ & $\begin{array}{l}\text { Feasible } \\
\text { Feasible } \\
\text { Feasible }\end{array}$ \\
\hline $\begin{array}{l}\text { Writing Procedure } \\
\text { Proportional font size and legible }\end{array}$ & 4 & 5 & & 9 & 90 & $\begin{array}{l}\text { Very } \\
\text { Feasible }\end{array}$ \\
\hline
\end{tabular}




\section{Comparison with Relevant Research}

Sari (2017: 81) suggests that the implementation of modules with a contextual approach to learning mechanics of Sports Science on the learning outcomes of 27 students shows that using the CTL learning model gets an overall average score of 4.58 and can be categorized as very high if the assessment refers to Riduwan (2015: 13). It shows that the module with a contextual approach to learning the Mechanics of Sports Science is suitable for teaching and learning activities. Under the Minimum Graduation Criteria rules, which apply a passing score to students in a subject, namely 75, the mean score of 27 students is 75.7. The conclusion is $74.1 \%$ of students have completed the learning, and $25.9 \%$ have not completed it. It shows that a module with a contextual approach to learning mechanics in Sports Science can help TKBB class X students understand the material to achieve the completeness set in the Bojonegoro 2 Vocational High School.

The research results from the journal of Irhamuddin (2017: 54) suggest that the implementation of learning using modules obtains an excellent average score. In student activities, the mean score is $85.11 \%$. Based on the categories, the performance of learning using modules is carried out very well.

The results of the research from Prabowo's thesis (2018: 74) suggest that the implementation of the direct learning model using modules at the first meeting gets a percentage of $87.00 \%$ (teachers) and $81.00 \%$ (students); at the second meeting, it gets a percentage of $88.00 \%$ (Teachers) and $84.00 \%$ (Students). Implementing the direct learning model for students in class XI Vocational High School 2 Bangkalan uses a very well implemented module; students can learn independently. It can be concluded that the implementation of the Sports Science module of building drawings in class XI TGB State Vocational School 2 Bangkalan is included in the outstanding category.

Justina (6: 2020) suggests that CTL-based module teaching materials as part of SSP development can be categorized as feasible. Expert validation results produce a coefficient of $0.7 \geq 0.5$ so that the product can be said to be valid. Based on the results of the questionnaire's limited trials, students get 28 out of a maximum score of 35 so that they are in an outstanding category.

Kalsum's thesis (93: 2017) suggests that students need (1) the development of modules based on Contextual Teaching and Learning (CTL), namely teaching materials that can solve problems that occur in the learning process; (2) modules that are developed using a model 4-D, which consists of 4 stages, but in this study only up to the third stage. The development begins with a defining stage consisting of the preliminary and final analysis, student analysis, concept analysis, task analysis, and specification of learning objectives. The second design stage consists of compiling tests, selecting media, selecting formats, and producing initial designs. Next, the development stage consists of expert validation and development tests, (3) the quality of the developed modules consisting of validity, practicality, and effectiveness. The module validity test data with revisions three times fulfills the correct category with an average score of all aspects of the validator's assessment of 3.39, so it is feasible to use. The module's practicality level meets the very positive category with the average score of the practicality trial results, namely, 3.57. This category indicates that the module is practical for use in the learning process. Meanwhile, the developed module's effectiveness fulfills the effective category, seeing that the average completeness of learning outcomes is $80.62 \%$.

\section{CONCLUSION}

Based on the results of the validation and discussion that has been presented, conclusions can be obtained, namely:

1. The validation of the module learning media validated by an expert lecturer in Sports Coaching Education, Surabaya State University, obtain a percentage value of $77.5 \%$ and can be categorized as a feasible learning media.

2. The results of a literature review by comparing five relevant studies using module learning media and using the Contextual Teaching and Learning (CTL) learning model result in the conclusion that the use of module learning media and the use of the Contextual Teaching and Learning (CTL) learning model in teaching and learning activities is very efficient and feasible to be used to improve student learning outcomes.

\section{SUGGESTION}

Based on research validation results and literature reviews, the learning media module in the Futsal course is expected to be applied in the classroom's teaching and learning process. The application can likely improve student learning outcomes and help students with high school graduate backgrounds who have never used the AutoCAD application. 


\section{REFERENCES}

Hamdayana, Jumana. 2014. Creative and Character Learning Models and Methods. Bogor: Ghalia, Indonesia.

Irhamuddin. 2017. Implementation of Modules in Class X TGB 2 in Building Materials Science Subject at SMK Negeri 1 Kemlagi. (Journal of Building Engineering Education Studies, Vol. 3; No.3, 2017), p. 44 $-56$.

Irawan. 2009. Basic Modern Futsal Techniques, Jakarta, Pena Pundi nAksara

Jaenudin. 2018. Development of Arduino Uno-based Passing Training Media in Futsal Sports. Journal of Applied Sport Science. Vol. 3 (1).

Laksmana, Justinus. 2011. Modern Futsal Tactics and Strategy. Jakarta, Be Champion.

Nurhadi, et al. 2003. Contextual Learning (CTL) and Its Application in the CBC. Malang: UNM.

Prabowo, Hasabi Vidi Koes. 2018. Implementing Modules for Building Drawing Subjects in the Building Drawing Engineering Department at SMK Negeri 2 Bangkalan. Thesis not published. Surabaya: Unesa.

Prastowo, Andi. 2011. Creative Guide to Making Innovative Teaching Materials. Yogyakarta: DIVA Press.

Riduwan. 2015. Basics of Statistics. Bandung: Alfabeta.

Suprijono. 2009. Cooperative Learning (PAIKEM Theory \& Application). Yogyakarta: Learning Library.

Justina, Sari. 2020. Development of CTL-Based Module Teaching Materials as Part of SSP Development. (Contextual Scientific Journal, Vol. 1, No.2, 2020), pp. 1-6.

Wiyono, Waluyo, 2015. The Influence of Learning Media Using Sketchup Program on the Ability to Draw Orthogonal Projection of Students at SMK Negeri 2 Surabaya, Journal of Building Engineering Education Studies Vol. 3 No.3, 2015.

Suparji, Wiyono, Limantara, 2019. Curriculum Adequacy on the Undergraduate Program of Building Technique-Faculty of Engineering State University of Surabaya towards the Vocational High School. International Journal of Recent Technology And Engineering, Vol. 8, issue 3. 